\title{
HEAT STABILITY OF ANTIBIOTICS RESIDUES IN MILK
}

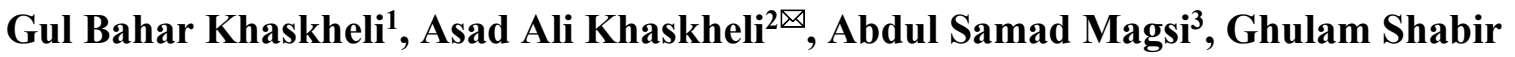 \\ Barham $^{1}$, Allah Jurio Khaskheli ${ }^{4}$, Arshad Ali Khaskheli ${ }^{5}$ \\ ${ }^{1}$ Department of Animal Products Technology, Sindh Agriculture University, Tando jam, Pakistan \\ ${ }^{2}$ Department of Animal Nutrition, Shaheed Benazir Bhutto University of Veterinary and Animal Sciences, \\ Sakrand, Pakistan \\ ${ }^{3}$ Department of Dairy Technology, Shaheed Benazir Bhutto University of Veterinary and Animal Sciences, \\ Sakrand, Pakistan \\ ${ }^{4}$ Department of Biotechnology, Sindh Agriculture University, Tando jam, Pakistan \\ ${ }^{5}$ Department of Poultry Husbandry, Sindh Agriculture University, Tando jam, Pakistan \\ 凶khaskhelias@gmail.com \\ https://doi.org/10.34302/crpjfst/2021.13.1.6

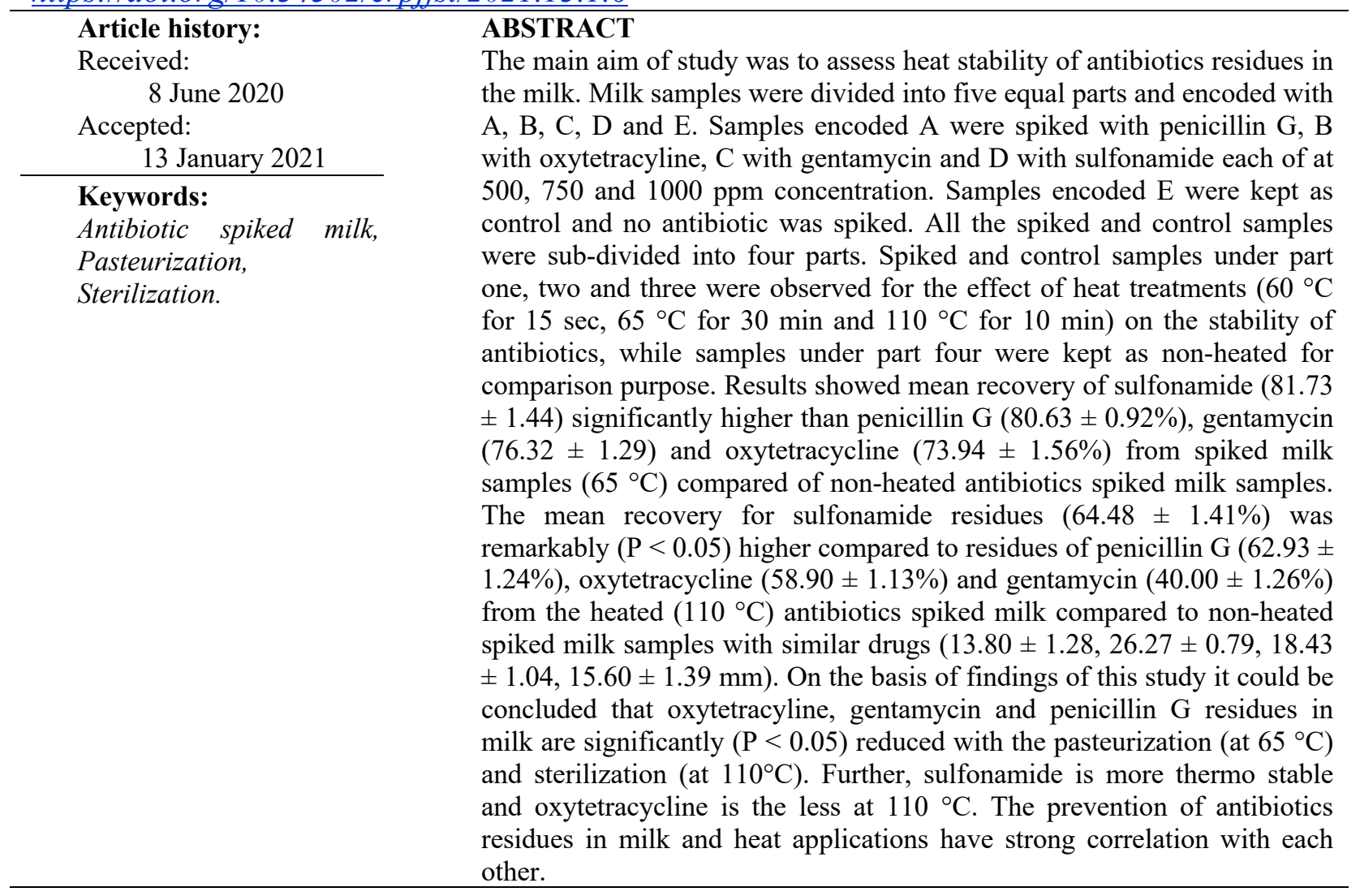

\section{Introduction}

Milk is a very nutritious food with higher level of carbohydrates, protein, fats, vitamins and minerals. It can be associated with health risks to consumers due to presence of zoonotic pathogens and antimicrobial drug residues. Consumers are much conscious about their safe food supply, which should be free from contamination, herbicides, pesticides, drugs and antibiotics, though otherwise may create severe health hazards, allergic reactions, carcinogenicity and bacterial resistance (Abbas et al. 2013). The misuse of antibiotics in animals lead to the development of resistant bacterial strains, and their transmission to human beings result significantly reduced 
efficacy of antibiotics. The antibiotics residues in milk are of great concern for dairy farmers, milk processors, consumers and regulatory agencies. The inactivation of these antibiotics residues is utmost important due to possible development of antibiotics resistance in humans (Berends et al. 2001).

Antibiotics are commonly used in domestic animals for the prevention and treatment of diseases. They are also used as growth promoters for enhancing the production of food producing animals. Excessive or improper use of antibiotics is of great concern due to appearance of residues in the milk (Shetandi and Sternesjo 2004). Antimicrobial residues in milk may pose potential health threats to the consumers in form of antibiotics resistance and allergies. They also influence the dairy industry by impairing the bacteriological processes used for manufacturing of dairy products (Conesa $e t$ al. 2008). The presence of antimicrobial substances in milk even in low concentrations is one of the main concerns of milk industry, as it poses risk of toxicity to public health, and can seriously influence the technological properties of milk and dairy products. For example, in the production of fermented milk products such compounds inhibit the growth of starter cultures (Jones 2008). Concentration of $1 \mathrm{ppb}$ delays the starter activity and decreases the acid and flavors the production during yoghurt or butter making, and also causes improper ripening of cheese. In past studies, heat treatment has been applied to reduce the level of antibiotics residues in milk (Khopaibool 2015). However, other study showed that antibiotics residues may not be totally destroyed under normal cooking procedures (Ghidini et al. 2002). The control of residues of veterinary drugs in food producing animals and animal products has been a cornerstone of the present agricultural and food policies for providing assurance to consumers about the safety and wholesomeness of their food (Moats 2007). In order to be safeguard human health, many countries have set up maximum residue limits (MRLs) of some antibiotics in milk. Milk samples exceeding prescribed MRL for penicillin G $4 \mu \mathrm{g} / \mathrm{l}$, sulfonamide MRL $100 \mu \mathrm{g} / \mathrm{l}$ and oxytetracyline $100 \mu \mathrm{g} / \mathrm{l}$, must be excluded from human consumption (Brady 2016). Failure to adhere these recommended periods has been reported to be the primary cause of violate levels of veterinary drugs in food (KuKanich et al. 2005).

Present study was therefore planned in order to observe the extent of antibiotics residues in the market milk and assess influence of various heat treatments on stability of antibiotics residues in milk.

\section{Materials and methods}

The present study was conducted during the year 2018, whereby antibiotics free milk samples were collected from the local markets of Sindh province and brought to the laboratory of department of Animal Products Technology for analysis purpose.

\subsection{Preparation of milk samples}

Milk samples were divided into five equal parts and encoded as A, B, C, D and E. Samples encoded A were spiked with penicillin G (Amino-Vet, manufac. ICI, Pakistan), B with oxytetracyline (Oxytetracycline, manufac. ICI, Pakistan), C with gentamycin (Refobacin, manufac. ICI, Pakistan), D with sulfonamide (Trisolizin, manufac. ICI, Pakistan) each of at concentration of 500, 750 and $1000 \mathrm{ppm}$ (AOAC 2000)[11], however samples encoded E were kept as control and no antibiotics were spiked. All the spiked and control samples were again sub-divided into four parts. Spiked and control samples under part one, two and three were observed for the effect of heat treatment (thermization; $60{ }^{\circ} \mathrm{C}$ for 15 seconds, pasteurization; $65{ }^{\circ} \mathrm{C}$ for $30 \mathrm{~min}$ and sterilization; $110{ }^{\circ} \mathrm{C}$ for $10 \mathrm{~min}$ ) on the stability of antibiotic residues, while under part four samples were kept as non-heated for comparison purpose. Turbidity test was used in order estimate microbial growth. 


\subsection{Preparation of media and isolation of Bacillus subtilis}

Nutrient agar was used against Bacillus subtilis [(Ehrenberg) Cohn, ATCC® $6051^{\mathrm{TM}}$ ]. Petri dishes containing nutrient agar were inoculated with test Bacillus subtilis. Milk samples were streaked on nutrient agar and petri dishes were incubated at $35^{\circ} \mathrm{C}$ under aerobic condition for 24 hours. Isolated colonies of Bacillus subtilis were picked-up and kept on clean glass slides. Gram staining was used for morphological characteristics of the isolates. The plates with purified colonies were stored in cryotube for further use. Moreover, purified colonies were picked from nutrient agar and inoculated in nutrient broth (HiMedia M002-100G Nutrient Broth, USA). Broth was incubated $\left(36 \pm 1{ }^{\circ} \mathrm{C}\right)$ for 24 hours. Before screening of test samples, this medium $(0.1 \mathrm{ml})$ was mixed with soft agar $(3 \mathrm{ml})$ and spread over nutrient agar (DeJonghe et al. 2010).

2.3.Screening of milk samples for the presence of antibiotics residues

A total of 10 samples were prepared and processed for assessing the effect of different heat treatments on stability of penicillin G, oxytetracyline, gentamycin and sulfonamide residues in milk. The blank disc of filter papers (Whatman 1, $12 \mathrm{~mm}$, CAT No. 1002-125, Bharat Instruments \& Chemicals Company, India) were completely dipped into each antibiotics spiked and control milk samples using forceps, and placed on the surface of agar medium containing the sensitive test organism (Bacillus subtilis). The plates were incubated $\left(36 \pm 1{ }^{\circ} \mathrm{C}\right)$ for 24 hours. The positive results (the presence of antibiotic residues) were manifested by formation of transparent zones around the disc and compared with control group. The zone size around each positive sample was measured with help of Vernier caliper. Since no any zone was appeared in control samples (no addition of antibiotics), the data on the zone size of heated and non-heated spiked milk samples were gathered for comparison purpose.

\subsection{Statistical analysis}

A computerized statistical package i.e. Student Edition of Statistix (SXW), Version 8.1 (Copyright 2005, Analytical Software, USA) was applied to assess the data. Statistical procedure of completely randomized analysis of variance (ANOVA) under linear models was used to observe the significant variations among the variables, and in case of the significant differences found among the means, the least significant difference (LSD) test was applied (Gomez and Gomez 1984). Difference was considered significant at $(\mathrm{P}<0.05)$.

\section{Results}

In present study, the stability of antibiotics residues in milk on different heat treatments was assessed. The results obtained are given in the subsequent sections.

\subsection{Penicillin G}

It was observed that the zones size of penicillin G spiked (500 - 1000 ppm) milk samples were significantly $(\mathrm{P}<0.05)$ reduced when heated at 60,65 and $110{ }^{\circ} \mathrm{C}$ compared to non-heated spiked (penicillin $\mathrm{G}$ ) milk samples. The average recovery percentages of penicillin $\mathrm{G}$ spiked milk samples with concentration of 500,750 and $1000 \mathrm{ppm}$ heated at $60^{\circ} \mathrm{C}$ were 95.36, 91.67 and $95.86 \%$ (reduction level) compared to non-heated $(23.60,26.40$ and $28.80 \mathrm{~mm}$ ) spiked milk samples with similar concentrations (Figure 1). 


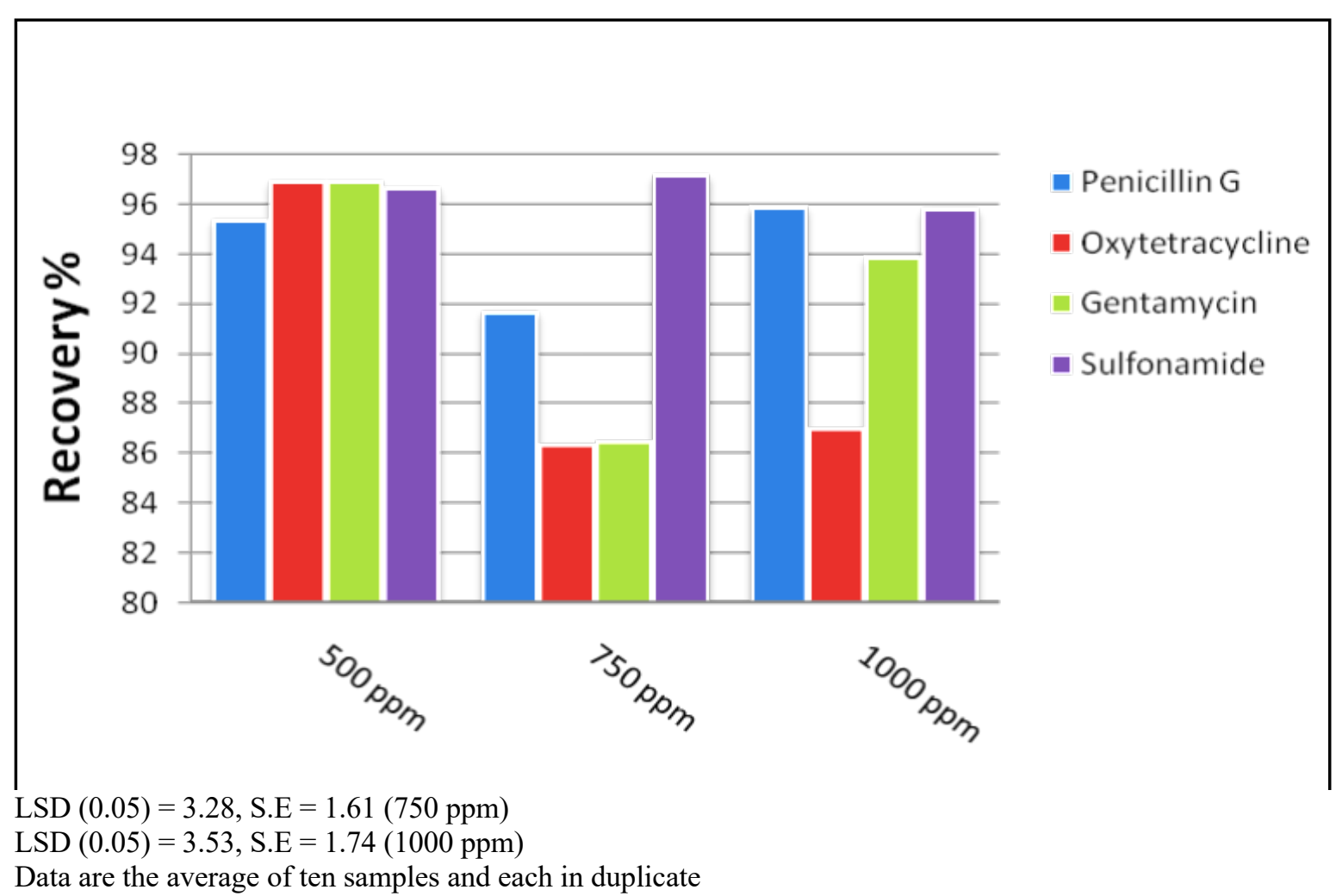

Figure 1. Recovery (\%) of antibiotics (penicillin G, oxytetracyline, gentamycin and sulfonamide) residues from spiked milk $(500,750,1000 \mathrm{ppm})$ heated at $60^{\circ} \mathrm{C}$ for few seconds.

The recovery percentages in zones size of penicillin $\mathrm{G}$ spiked $(500,750$ and $1000 \mathrm{ppm})$ milk samples heated at $65{ }^{\circ} \mathrm{C}$ were found $83.53,71.22$ and $87.16 \%$, respectively with overall reduction of $16.47,28.78$ and $12.84 \%$, respectively as shown in Table 1 . However, at $110{ }^{\circ} \mathrm{C}$ recovery percentages in zone size were recorded $73.31,64.06$ and $51.41 \%$, respectively (Figure 2) with average reduction of 26.69 , 35.94 and $48.59 \%$ (Table 1). Mean reduction percentage in zone size of penicillin G spiked $(500-1000 \mathrm{ppm})$ samples was highest $(37.07 \%)$ at $110{ }^{\circ} \mathrm{C}$ followed by at $65{ }^{\circ} \mathrm{C}$ $(19.36 \%)$ and at $60{ }^{\circ} \mathrm{C}(5.70 \%)$ compared to zone size of non-heated penicillin $\mathrm{G}$ spiked milk samples (500 - 1000 ppm) as shown in Table 2.

\subsection{Oxytetracycline}

In the present study, average zones size of oxytetracycline spiked milk samples $(500,750$ and $1000 \mathrm{ppm}$ ) were detected as $12.60,16.00$ and $18.20 \mathrm{~mm}$, respectively. The zones size significantly $(\mathrm{P}<0.05)$ reduced in oxytetracycline spiked milk samples heated at 60,65 and $110^{\circ} \mathrm{C}$. The average recovery levels in oxytetracycline spiked milk (with concentration of 500, 750 and $1000 \mathrm{ppm}$ ) were $96.91,86.31$ and $86.96 \%$ with average reduction level of 3.09, 13.69 and $13.04 \%$, respectively at $60{ }^{\circ} \mathrm{C}$ (Figure 1 and Table 1). Antibiotics residues in oxyteracycline spiked milk heated at $65{ }^{\circ} \mathrm{C}$ were observed as 76.44 , 75.84 and $70.36 \%$ with reduction in zones size of $23.56,24.16$ and $29.64 \%$, respectively (Figure 2). However, at $110{ }^{\circ} \mathrm{C}$ residues reduced from 58.86, 60.68 and $57.77 \%$ to $41.14, \quad 39.32$ and $42.23 \%$, respectively compared to non-heated oxytetracycline spiked milk samples $(12.60,16.00$ and $18.20 \mathrm{~mm})$ with similar concentration level (Figure 3 and Table 1). The average zone size of oxytetracycline spiked (500 - 1000 ppm) milk samples heated at $110{ }^{\circ} \mathrm{C}$ was reduced up to $41.10 \%$. Sample heated at $65{ }^{\circ} \mathrm{C}$ and $60{ }^{\circ} \mathrm{C}$ showed reduction in zones size up to 26.06 and 
$10.18 \%$, respectively compared to average zone size of non-heated oxytetracycline spiked milk samples with similar concentration $(15.60 \mathrm{~mm})$ as tabulated in Table 2. Present results suggested that heating of milk up to $110{ }^{\circ} \mathrm{C}$ does not completely eliminate oxytetracycline residues level.

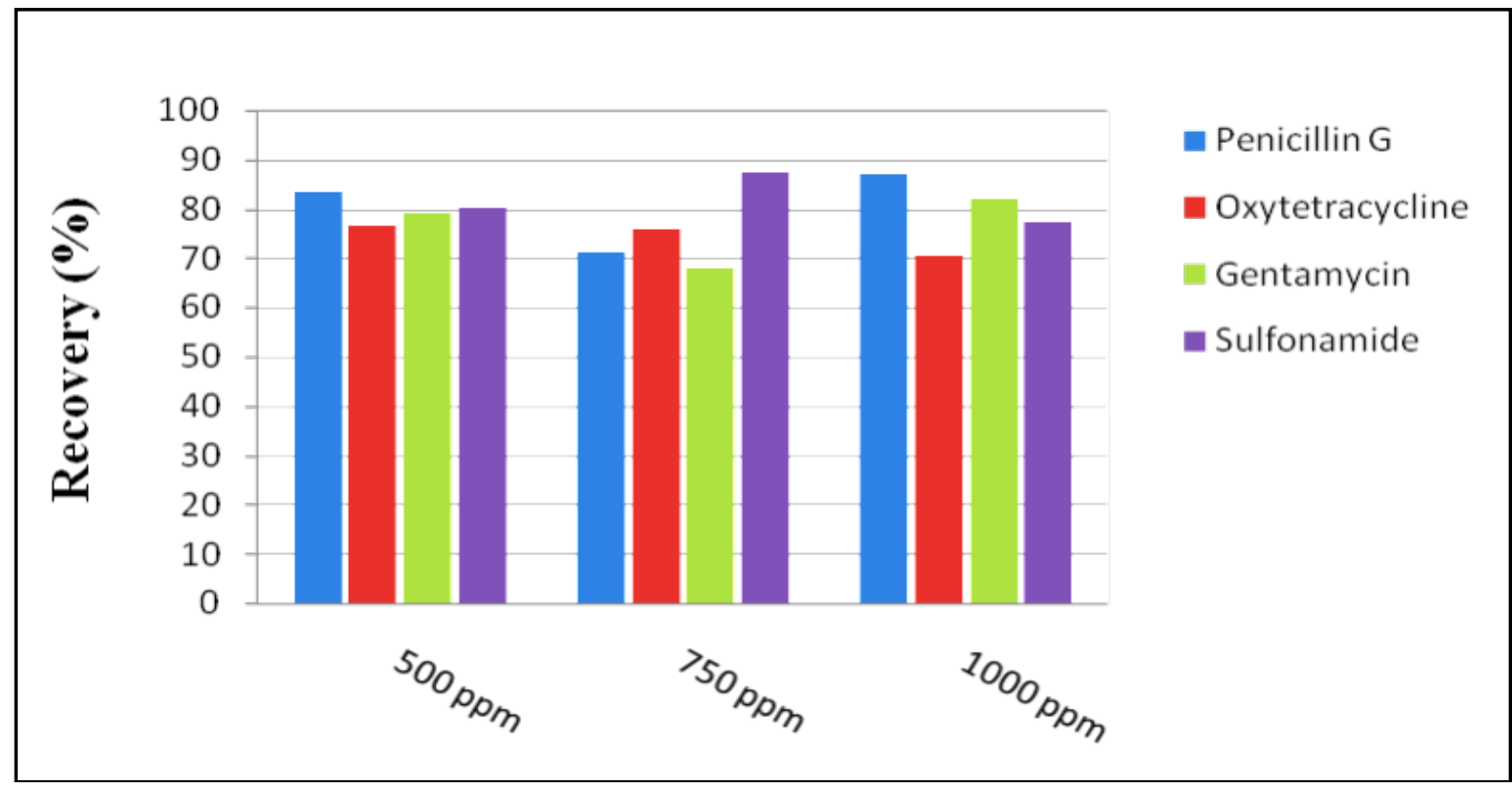

\footnotetext{
$\operatorname{LSD}(0.05)=4.91, \mathrm{~S} . \mathrm{E}=2.42(500 \mathrm{ppm})$

$\operatorname{LSD}(0.05)=3.72, \mathrm{~S} . \mathrm{E}=1.83(750 \mathrm{ppm})$

$\operatorname{LSD}(0.05)=2.92, \mathrm{~S} . \mathrm{E}=1.44(1000 \mathrm{ppm})$

Data are the average of ten samples and each in duplicate
}

Figure 2. Recovery (\%) of antibiotics (penicillin G, oxytetracyline, gentamycin and sulfonamide) residues from spiked milk $(500,750,1000 \mathrm{ppm})$ heated at $65^{\circ} \mathrm{C}$ for $30 \mathrm{~min}$.

\subsection{Gentamycin}

Average zones size of non-heated gentamycin spiked milk samples $(500,750$ and $1000 \mathrm{ppm}$ ) in the present study appeared as $15.80,18.40$ and $21.10 \mathrm{~mm}$, respectively (Table $1)$. The zones size were remarkably $(\mathrm{P}<0.05)$ reduced in gentamycin spiked milk samples heated at 60,65 and $110{ }^{\circ} \mathrm{C}$. The average recovery percentages of antibiotics residues from gentamycin spiked milk $(500,750$ and $1000 \mathrm{ppm})$ at $60{ }^{\circ} \mathrm{C}$ appeared $96.87,86.43$ and $93.87 \%$ with decreased zone size of $3.13,13.57$ and $6.13 \%$ (Figure 1). The recovery percentages of residues from gentamycin spiked milk samples heated at $65{ }^{\circ} \mathrm{C}$ revealed as $79.20,67.98$ and $82.07 \%$ with zone size reduction 20.80, 32.02 and 17.93\% (Figure 2 and Table 1). Whereas spiked milk heated at $110{ }^{\circ} \mathrm{C}$ (Figure 3) revealed recovery of antibiotics residues 44.33, 32.08 and $43.61 \%$ with zones size reduction up to $55.77,67.92$ and $56.39 \%$, respectively compared to nonheated gentamycin spiked milk samples (500, 750 and $1000 \mathrm{ppm}$ ). The average reduction in zones size of gentamycin spiked milk samples $(500-1000 \mathrm{ppm})$ heated at $110{ }^{\circ} \mathrm{C}$ was highest $(60.03 \%)$ followed by heated at $65{ }^{\circ} \mathrm{C}(23.58 \%)$ and at $60{ }^{\circ} \mathrm{C}(7.61 \%)$ as shown in the Table 1 . 


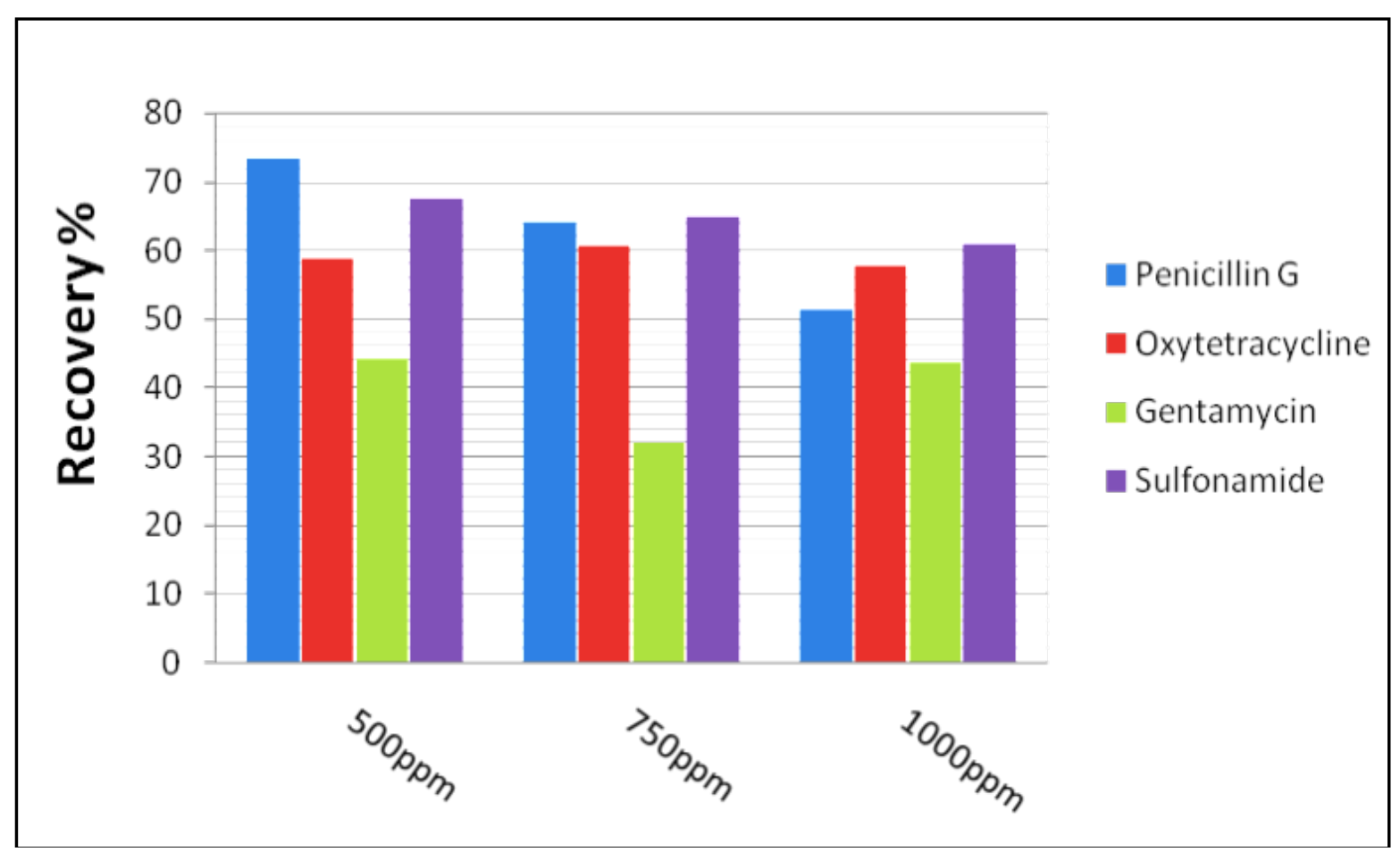

$\operatorname{LSD}(0.05)=3.96, \mathrm{~S} . \mathrm{E}=1.95(500 \mathrm{ppm})$

$\operatorname{LSD}(0.05)=4.17, \mathrm{~S} . \mathrm{E}=2.05(750 \mathrm{ppm})$

$\operatorname{LSD}(0.05)=3.01, \mathrm{~S} . \mathrm{E}=1.48(1000 \mathrm{ppm})$

Data are the average of ten samples and each in duplicate.

Figure 3. Recovery (\%) of antibiotics (penicillin G, oxytetracyline, gentamycin and sulfonamide) residues from spiked milk $(500,750,1000 \mathrm{ppm})$ heated at $110^{\circ} \mathrm{C}$ for $10 \mathrm{~min}$.

\subsection{Sulfonamide}

Sulfonamide spiked milk (500, 750 and $1000 \mathrm{ppm})$ heated at $60{ }^{\circ} \mathrm{C}$ appeared as 96.66 , 97.14 and $95.77 \%$ (decreased to $3.34,2.86$ and $3.33 \%$ ) of total non-heat zone size respectively $(11.60,13.40$ and $16.40 \mathrm{~mm}$ ) (Figure 1 and Table). The recovery residues percentages were $80.34,87.47$ and $77.42 \%$ and that reduced to $19.66,12.53$ and $22.58 \%$ when heated at $65^{\circ} \mathrm{C}$. At $110 \quad{ }^{\circ} \mathrm{C}$ observed residues recovery percentage $67.44,65.00$ and $61.00 \%$ reduced to $32.56,35.00$ and $39.00 \%$, respectively (Figure 2 and Figure 3). The mean reduction level in zones size of sulfonamide spiked milk (500 $1000 \mathrm{ppm}$ ) samples was higher at $110{ }^{\circ} \mathrm{C}$
$(32.52 \%)$ and lower at $60{ }^{\circ} \mathrm{C}(3.48 \%)$ with intermediate level of $18.25 \%$ at $65{ }^{\circ} \mathrm{C}$ compared to mean zones size of non-heated sulfonamide spiked milk samples $(13.80 \mathrm{~mm})$ as summarized in Table 2. Findings further indicate that thermization process $\left(60^{\circ} \mathrm{C}\right.$ for 15 seconds) has no significant $(\mathrm{P}>0.05)$ effect on the reduction of residues in sulfonamide contaminated milk. While sterilization process $\left(110{ }^{\circ} \mathrm{C}\right.$ for $\left.10 \mathrm{~min}\right)$ reduces up to $50 \%$ level of residues in sulfonamide spiked milk. Severe heating is required for complete reduction of sulfonamide residues from milk. 
Table 1. Effect of various heat treatments on antibiotics (penicillin G, oxytetracycline, gentamycin and sulfonamide) spiked milk samples (500, 750 and $1000 \mathrm{ppm})$

\begin{tabular}{|c|c|c|c|c|c|c|c|c|}
\hline \multirow{3}{*}{ Concentration } & \multicolumn{4}{|c|}{ Zone size of penicillin $\mathrm{G}(\mathrm{mm}) 500 \mathrm{ppm}$} & \multicolumn{4}{|c|}{ Zone size oxytetracycline (mm) $500 \mathrm{ppm}$} \\
\hline & \multirow{2}{*}{$\begin{array}{l}\text { Non } \\
\text { heated }\end{array}$} & \multicolumn{3}{|l|}{ Heated } & \multirow{2}{*}{$\begin{array}{l}\text { Non } \\
\text { heated }\end{array}$} & \multicolumn{3}{|l|}{ Heated } \\
\hline & & $\left(60^{\circ} \mathrm{C}\right)$ & $\left(65^{\circ} \mathrm{C}\right)$ & $\left(110{ }^{\circ} \mathrm{C}\right)$ & & $\left(60^{\circ} \mathrm{C}\right)$ & $\left(65^{\circ} \mathrm{C}\right)$ & $\left(110{ }^{\circ} \mathrm{C}\right)$ \\
\hline Maximum & 24.00 & 23.00 & 20.00 & 18.00 & 14.00 & 13.00 & 11.00 & 8.00 \\
\hline Minimum & 23.00 & 22.00 & 19.00 & 16.00 & 12.00 & 11.00 & 9.00 & 7.00 \\
\hline Mean & 23.600 & 22.500 & 19.700 & 17.300 & 12.60 & 12.200 & 9.600 & 7.400 \\
\hline SE \pm & 0.163 & 0.163 & 0.152 & 0.213 & 0.221 & 0.2000 & 0.221 & 0.163 \\
\hline \multirow{3}{*}{ Concentration } & \multicolumn{4}{|c|}{ Zone size of penicillin $G(\mathrm{~mm}) 750 \mathrm{ppm}$} & \multicolumn{4}{|c|}{ Zone size oxytetracycline (mm) $750 \mathrm{ppm}$} \\
\hline & \multirow{2}{*}{$\begin{array}{l}\text { Non } \\
\text { heated }\end{array}$} & \multicolumn{3}{|l|}{ Heated } & \multirow{2}{*}{$\begin{array}{l}\text { Non } \\
\text { heated }\end{array}$} & \multicolumn{3}{|l|}{ Heated } \\
\hline & & $\left(60^{\circ} \mathrm{C}\right)$ & $\left(65^{\circ} \mathrm{C}\right)$ & $\left(110{ }^{\circ} \mathrm{C}\right)$ & & $\left(60^{\circ} \mathrm{C}\right)$ & $\left(65^{\circ} \mathrm{C}\right)$ & $\left(110{ }^{\circ} \mathrm{C}\right)$ \\
\hline Maximum & 27.00 & 25.00 & 20.00 & 19.00 & 17.00 & 15.00 & 13.00 & 10.00 \\
\hline Minimum & 26.00 & 23.00 & 18.00 & 15.00 & 15.00 & 13.00 & 11.00 & 9.00 \\
\hline Mean & 26.400 & 24.200 & 18.800 & 16.900 & 16.00 & 13.800 & 12.00 & 9.700 \\
\hline $\mathbf{S E} \pm$ & 0.163 & 0.249 & 0.249 & 0.504 & 0.210 & 0.2000 & 0.210 & 0.152 \\
\hline \multirow{3}{*}{ Concentration } & \multicolumn{4}{|c|}{ Zone size of penicillin G (mm) 1000 ppm } & \multicolumn{4}{|c|}{ Zone size oxytetracycline $(\mathrm{mm}) 1000 \mathrm{ppm}$} \\
\hline & \multirow{2}{*}{$\begin{array}{l}\text { Non } \\
\text { heated }\end{array}$} & \multicolumn{3}{|l|}{ Heated } & \multirow{2}{*}{$\begin{array}{l}\text { Non } \\
\text { heated }\end{array}$} & \multicolumn{3}{|l|}{ Heated } \\
\hline & & $\left(60^{\circ} \mathrm{C}\right)$ & $\left(65^{\circ} \mathrm{C}\right)$ & $\left(110{ }^{\circ} \mathrm{C}\right)$ & & $\left(60^{\circ} \mathrm{C}\right)$ & $\left(65^{\circ} \mathrm{C}\right)$ & $\left(110{ }^{\circ} \mathrm{C}\right)$ \\
\hline Maximum & 29.00 & 28.00 & 26.00 & 16.00 & 19.00 & 17.00 & 14.00 & 10.00 \\
\hline Minimum & 28.00 & 27.00 & 24.00 & 14.00 & 17.00 & 15.00 & 12.00 & 11.00 \\
\hline Mean & 28.800 & 27.600 & 25.100 & 14.800 & 18.200 & 15.800 & 12.800 & 10.400 \\
\hline SE \pm & 0.133 & 0.163 & 0.233 & 0.200 & 0.2000 & 0.2000 & 0.2000 & 0.163 \\
\hline \multirow{3}{*}{ Concentration } & \multicolumn{4}{|c|}{ Zone size of gentamycin $(\mathrm{mm}) 500 \mathrm{ppm}$} & \multicolumn{4}{|c|}{ Zone size sulfonamide (mm) 500 ppm } \\
\hline & Non & Heated & & & Non & Heated & & \\
\hline & heated & $\left(60^{\circ} \mathrm{C}\right)$ & $\left(65^{\circ} \mathrm{C}\right)$ & $\left(110{ }^{\circ} \mathrm{C}\right)$ & heated & $\left(60^{\circ} \mathrm{C}\right)$ & $\left(65^{\circ} \mathrm{C}\right)$ & $\left(110{ }^{\circ} \mathrm{C}\right)$ \\
\hline Maximum & 16.00 & 16.00 & 13.00 & 8.00 & 13.00 & 12.00 & 10.00 & 8.00 \\
\hline Minimum & 15.00 & 15.00 & 12.00 & 6.00 & 11.00 & 10.00 & 9.00 & 7.00 \\
\hline Mean & 15.800 & 15.300 & 12.500 & 7.00 & 11.600 & 11.300 & 9.300 & 7.800 \\
\hline $\mathbf{S E} \pm$ & 0.133 & 0.152 & 0.166 & 0.210 & 0.221 & 0.213 & 0.152 & 0.133 \\
\hline Concentration & Zone si & of gental & $\operatorname{cin}(\mathbf{m m})$ & 0 ppm & Zone si & sulfonan & de $(\mathrm{mm})$ & ppm \\
\hline & Non & Heated & & & Non & Heated & & \\
\hline & heated & $\left(60^{\circ} \mathrm{C}\right)$ & $\left(65^{\circ} \mathrm{C}\right)$ & $\left(110{ }^{\circ} \mathrm{C}\right)$ & heated & $\left(60^{\circ} \mathrm{C}\right)$ & $\left(65^{\circ} \mathrm{C}\right)$ & $\left(110{ }^{\circ} \mathrm{C}\right)$ \\
\hline Maximum & 19.00 & 17.00 & 13.00 & 7.00 & 13.00 & 12.00 & 10.00 & 8.00 \\
\hline Minimum & 18.00 & 15.00 & 12.00 & 5.00 & 11.00 & 10.00 & 9.00 & 7.00 \\
\hline Mean & 18.400 & 15.900 & 12.500 & 5.900 & 11.600 & 11.300 & 9.300 & 7.800 \\
\hline $\mathrm{SE} \pm$ & 0.163 & 0.179 & 0.166 & 0.233 & 0.221 & 0.213 & 0.152 & 0.133 \\
\hline Concentration & Zone si & of gental & $\operatorname{cin}(\mathrm{mm})$ & 000 ppm & Zone si & sulfonan & de $(\mathrm{mm})$ & $00 \mathrm{ppm}$ \\
\hline & Non & Heated & & & Non & Heated & & \\
\hline & heated & $\left(60^{\circ} \mathrm{C}\right)$ & $\left(65^{\circ} \mathrm{C}\right)$ & $\left(110{ }^{\circ} \mathrm{C}\right)$ & heated & $\left(60^{\circ} \mathrm{C}\right)$ & $\left(65^{\circ} \mathrm{C}\right)$ & $\left(110{ }^{\circ} \mathrm{C}\right)$ \\
\hline Maximum & 22.00 & 21.00 & 18.00 & 10.00 & 17.00 & 17.00 & 14.00 & 11.00 \\
\hline Minimum & 20.00 & 19.00 & 17.00 & 8.00 & 16.00 & 15.00 & 12.00 & 9.00 \\
\hline Mean & 21.100 & 19.800 & 17.300 & 9.200 & 16.400 & 15.800 & 12.700 & 10.00 \\
\hline $\mathbf{S E} \pm$ & 0.179 & 0.249 & 0.152 & 0.249 & 0.163 & 0.200 & 0.213 & 0.210 \\
\hline
\end{tabular}

Table 2. Effect of various heat treatments on antibiotics (Penicillin G, Oxytetracycline, Gentamycin and Sulfonamide) spiked milk samples (500 - $1000 \mathrm{ppm})$

\begin{tabular}{|c|c|c|c|c|c|}
\hline \multicolumn{2}{|c|}{ Heat treatment at $60^{\circ} \mathbf{C}$} \\
\hline Antibiotics & $\begin{array}{c}\text { No heat } \\
\text { zone size (mm) }\end{array}$ & $\begin{array}{c}\text { zone } \\
\text { size } \\
(\mathrm{mm})\end{array}$ & $\begin{array}{r}\text { Reco } \\
\text { very (\%) }\end{array}$ & $\begin{array}{c}\text { Reduc } \\
\text { tion (\%) }\end{array}$ & $\begin{array}{c}\text { Standard } \\
\text { error }\end{array}$ \\
\hline Penicillin G & 26.27 & 24.76 & $\begin{array}{c}94.2 \\
9\end{array}$ & 5.76 & 0.79 \\
\hline Oxytetracycline & 15.60 & 13.93 & 90.0 & 10.18 & 1.39 \\
\hline
\end{tabular}


Khaskheli et al./ Carpathian Journal of Food Science and Technology, 2021, 13(1), 63-74

\begin{tabular}{|c|c|c|c|c|c|}
\hline & & & 6 & & \\
\hline Gentamycin & 18.43 & 17.00 & $\begin{array}{l}92.3 \\
9\end{array}$ & 7.61 & 1.04 \\
\hline Sulfonamide & 13.80 & 13.34 & $\begin{array}{l}96.5 \\
2\end{array}$ & 3.48 & 1.28 \\
\hline \multicolumn{6}{|c|}{ Heat treatment at $65^{\circ} \mathrm{C}$} \\
\hline Antibiotics & $\begin{array}{c}\text { No heat } \\
\text { zone size }(\mathrm{mm})\end{array}$ & $\begin{array}{l}\text { zone } \\
\text { size } \\
(\mathrm{mm})\end{array}$ & $\begin{array}{r}\text { Reco } \\
\text { very }(\%)\end{array}$ & $\begin{array}{l}\text { Reduc } \\
\text { tion }(\%)\end{array}$ & $\begin{array}{l}\text { Standard } \\
\text { error }\end{array}$ \\
\hline Penicillin G & 26.27 & 21.20 & $\begin{array}{l}80.6 \\
3\end{array}$ & 19.36 & 0.92 \\
\hline Oxytetracycline & 15.60 & 11.47 & $\begin{array}{l}73.9 \\
4\end{array}$ & 26.06 & 1.55 \\
\hline Gentamycin & 18.43 & 14.10 & $2^{76.3}$ & 23.58 & 1.29 \\
\hline Sulfonamide & 13.80 & 11.23 & $\begin{array}{l}81.7 \\
3\end{array}$ & 18.25 & 1.44 \\
\hline \multicolumn{6}{|c|}{ Heat treatment at $110{ }^{\circ} \mathrm{C}$} \\
\hline Antibiotics & $\begin{array}{c}\text { No heat } \\
\text { zone size }(\mathrm{mm})\end{array}$ & $\begin{array}{l}\text { zone } \\
\text { size } \\
(\mathrm{mm})\end{array}$ & $\begin{array}{r}\text { Reco } \\
\text { very }(\%)\end{array}$ & $\begin{array}{l}\text { Reduc } \\
\text { tion }(\%)\end{array}$ & $\begin{array}{l}\text { Standard } \\
\text { error }\end{array}$ \\
\hline Penicillin G & 26.27 & 16.33 & $\begin{array}{l}62.9 \\
3\end{array}$ & 37.07 & 1.24 \\
\hline Oxytetracycline & 15.60 & 9.17 & $\begin{array}{l}58.9 \\
0\end{array}$ & 41.10 & 1.13 \\
\hline Gentamycin & 18.43 & 7.37 & $\begin{array}{l}40.0 \\
0 \\
\end{array}$ & 60.00 & 1.26 \\
\hline Sulfonamide & 13.80 & 8.83 & $\begin{array}{l}64.4 \\
8 \\
\end{array}$ & 32.52 & 1.41 \\
\hline
\end{tabular}

\subsection{Discussions}

Current study was carried out for observing the stability of antibiotics residues in the milk with respect to different heat treatments. It was observed that average recovery percentage of penicillin G spiked milk samples $(500,750$ and $1000 \mathrm{ppm}$ ) heated at $60{ }^{\circ} \mathrm{C}$ was $95.36,91.67$ and $95.86 \%$ compared to non-heated spiked milk samples. Recovery percentages of zones size $65{ }^{\circ} \mathrm{C}$ were $83.53,71.22$ and $87.16 \%$. However, at $110{ }^{\circ} \mathrm{C}$ zones size were recorded 73.31, 64.06 and 51.41\%. Mean reduction percentage in zones size of penicillin G spiked $(500-1000 \mathrm{ppm})$ samples was highest at 110 ${ }^{\circ} \mathrm{C}$ followed by at $65{ }^{\circ} \mathrm{C}$ and at $60{ }^{\circ} \mathrm{C}$ compared to non-heated spiked milk samples. Our results are not in consistent with the findings of (Loksuwan 2002) who reported non-significant $(\mathrm{P}>0.05)$ reduction in penicillin G spiked milk (500 - 1000 ppm) heated at $65{ }^{\circ} \mathrm{C}$ for $30 \mathrm{~min}$. The variation in the results may be due to change in the efficacy of antibiotics with respect to producing company as well experimental site. Change in the results may also because of heat treatment methods used during the research. Our results are supported by another research, where effects of heat treatments on stability of $\beta$-lactams in milk were studied. Their results indicated that in sterilization, the heat treatment of $120^{\circ} \mathrm{C}$ for 20 min leads to high degradation of $\beta$-lactam antibiotics including penicillin G. The degradation rates of penicillin remains between $47.6 \%$ and $84 \%$ (Roca et al. 2011). Results obtained by Zorraquino et al. (2008) are also supportive to present study. They indicated that pasteurization at $63{ }^{\circ} \mathrm{C}$ for $30 \mathrm{~min}$ shows low antimicrobial activity loss for penicillin (between 7\% and 11\%) compared to cephalosporins (between 6\% and 18\%). Our 
results show significant relevance with (Konec`ny 2007), who observed low-heat inactivation percentage $(10 \%)$ in penicillin $\mathrm{G}-$ fortified milk samples heated at $83{ }^{\circ} \mathrm{C}$ for 10 min. This percentage increased to 30 and $32 \%$ when milk was treated at $70{ }^{\circ} \mathrm{C}$ for $30 \mathrm{~min}$ and $100{ }^{\circ} \mathrm{C}$ for $30 \mathrm{~min}$, respectively. Jacquet and Auxepaules (2012) carried out a low temperature-long-time pasteurization $\left(63{ }^{\circ} \mathrm{C}\right.$ for $30 \mathrm{~min}$ ). They obtained low inactivation percentages for ampicillin (1.7\%) and penicillin G (2.6\%); values supportive to those that appear in this study. Tropilo (2015), on the other hand, obtained an inactivation percentage of $15.2 \%$ in aqueous penicillin solutions at $\mathrm{pH}$ 7.0 when heated at $80{ }^{\circ} \mathrm{C}$ for $15 \mathrm{~min}$. However, when these solutions were heated to $121{ }^{\circ} \mathrm{C}$ for $15 \mathrm{~min}$, the percentage increased greatly to $81.5 \%$. If we compare them to what is obtained using milk samples, then this increase in the inactivation percentage could be attributed to a possible protective effect of the milk's fat content on the antimicrobial molecules. The work of Broggler et al. (2015) indicated that if a moderate dose of penicillin (50,000 units) is administered, a significant amount ( 0.14 units/ $\mathrm{ml}$ ) is detectable in milk from the treated animal 72 hours later. Further, penicillin has been reported in one of the first reported surveys of antibiotics in market milk which was conducted in New York State in 1951 (Kosikowsky et al. 2013). A total of 1,794 samples of fresh, blended and pasteurized whole milk were obtained from dairy plants or route wagons in 36 counties. Six percent of the samples tested contained antibiotics and they were present in the range of $0.05-0.1$ unit per $\mathrm{ml}$ of milk. Penicillin was found most frequently appeared antibiotic in the milk during the spring of the year. The first survey was made on both raw and pasteurized milk obtained from seven of the 16 Food and Drug Administration districts and showed that 3.2\% of 94 samples contained penicillin and $1.07 \%$ contained bacitracin. These all reports strongly support to our results (Welch 2005; Welch et al. 2010 ).
In present study, the average recovery levels in oxytetracycline spiked milk $(500,750$ and $1000 \mathrm{ppm}$ ) were observed 96.91, 86.31 and $86.96 \%$ with average reduction levels of 3.09 , 13.69 and $13.04 \%$ at $60{ }^{\circ} \mathrm{C}$. Antibiotics residues at $65{ }^{\circ} \mathrm{C}$ were observed 76.44, 75.84 and $70.36 \%$, however at $110{ }^{\circ} \mathrm{C}$ residues reduced. The average zones size of oxytetracycline spiked (500 - 1000 ppm) milk samples heated at $110{ }^{\circ} \mathrm{C}$ showed reduction up to $41.10 \%$, while at $65{ }^{\circ} \mathrm{C}$ and $60{ }^{\circ} \mathrm{C}$ reduction was up to 26.06 and $10.18 \%$. Loksuwan (2002) studied the effects of low-temperature longtime (LTLT) pasteurization $\left(63{ }^{\circ} \mathrm{C} / 30 \mathrm{~min}\right.$ ) on oxytetracycline residues in raw milk. The oxytetracycline residues were in samples with concentration of $100 \mu \mathrm{g} \cdot \mathrm{l}^{-1}$ inactivated to such an extent that they could not be detected. The starting oxytetracycline concentrations were found to be dropped by $86.7 \%$. Hsieh et al. (2011) studied the effects of the heat treatments on tetracycline thermostability, using doubledistilled water as a matrix. They used two different heating temperatures $\left(100^{\circ} \mathrm{C}, 121^{\circ} \mathrm{C}\right)$ with the same time of exposure $(15 \mathrm{~min})$. Their findings showed that higher temperatures (121 ${ }^{\circ} \mathrm{C} / 15 \mathrm{~min}$ ) cause tetracycline degradation of up to $99 \%$. At $100{ }^{\circ} \mathrm{C}$ the degradation was less extensive, amounting to as little as $54.4 \%$. The results of this study clearly show that the degree of oxytetracycline degradation is temperature dependent and these same results have been observed in our study. In support our study, Hassani et al. (2008) set out to determine the thermostability of oxytetracycline in McIlvaine buffer with varying $\mathrm{pH}$ value $(\mathrm{pH}$ 7.0, 5.5 and 4.0) and ultra-high temperatures ranging from 110 to $140{ }^{\circ} \mathrm{C}$. The results of the study showed that sterilization $\left(118{ }^{\circ} \mathrm{C}\right.$ per 30 $\min$ and $121{ }^{\circ} \mathrm{C}$ per $20 \mathrm{~min}$ ) reduces the concentration of oxytetracycline to negligible amounts (less than 0.01\%). The ultra-high temperature treatment on the other hand, reduces oxytetracycline concentrations by more than $40 \%$. At $135^{\circ} \mathrm{C}$ per $15 \mathrm{sec}$ the ultra-high temperature treatment inactivate oxytetracycline residues by $44 \%$. While the sterilization process degrades oxytetracycline in 
milk by more than $98 \%$. Few others reported that pasteurization of milk which contained antibiotics did not inactivate chlortetracycline, chloramphenicol, streptomycin and oxytetracycline (Overby 2015). These results are somewhat change from our study. Difference may be related to the variation in heat treatment methods. Shahani (2011) reported a reduction of $9.3,14.2,18.4,22.5$ and 25.4 percent in the potency of chlortetracycline in milk which were pasteurized at $143{ }^{\circ} \mathrm{F}$ for $10,20,30,40$ and 50 minutes, respectively. The loss in potency was $13.5,20.1,27.1,32.5$ and 38.2 percent when milk were pasteurized at $160{ }^{\circ} \mathrm{F}$ for the same time periods. These results strongly agree with our reports. More recently it has been found that pasteurization at $143{ }^{\circ} \mathrm{F}$ for 30 minutes result 30 percent loss of oxytetracycline activity when 0.84 to $1.0 \mathrm{ug}$ of the antibiotics is present per $\mathrm{ml}$ of milk. An increase in pasteurization temperature to $160^{\circ} \mathrm{F}$ results in a $4<$ percent loss in activity after 30 minutes of heating. Oxytetracycline in milk is completely inactivated by heating to $160{ }^{\circ} \mathrm{F}$ for 190 minutes, $175^{\circ} \mathrm{F}$ for 92 minutes and $185^{\circ} \mathrm{F}$ for 60 minutes (Shahani 2009). These results strongly support to our findings regarding oxytetracycline.

Further, the average recovery percentages of antibiotics residues from gentamycin spiked milk (500, 750 and $1000 \mathrm{ppm}$ ) at $60{ }^{\circ} \mathrm{C}$ appeared 96.87, 86.43 and $93.87 \%$ with decrease zones size of $3.13,13.57$ and $6.13 \%$. The recovery percentages of residues at $65{ }^{\circ} \mathrm{C}$ were $79.20,67.98$ and $82.07 \%$, whereas, at 110 ${ }^{\circ} \mathrm{C}$ were $44.33,32.08$ and $43.61 \%$. The average reduction in zones size of gentamycin spiked milk samples (500 - $1000 \mathrm{ppm})$ heated at 110 ${ }^{\circ} \mathrm{C}$ was highest followed by heated at $65{ }^{\circ} \mathrm{C}$ and $60{ }^{\circ} \mathrm{C}$. Our findings are in consistent with the study of (Omar and Eltinay 2008). They reported same reduction pattern of gentamycin as investigated in current research. Few other authors reported that heat treatment at $60{ }^{\circ} \mathrm{C}$ for $30 \mathrm{~min}$ does not inactivate the residues of gentamycin, while classic sterilization $\left(120^{\circ} \mathrm{C}\right.$ for $20 \mathrm{~min}$ ) shows high heat inactivation ( > 95\%) for the residues of gentamycin.
Sulfonamide spiked milk (500, 750 and $1000 \mathrm{ppm}$ ) heated at $60{ }^{\circ} \mathrm{C}$ appeared as 96.66 , 97.14 and $95.77 \%$. The recovery residues percentages were $80.34,87.47$ and $77.42 \%$ at $65{ }^{\circ} \mathrm{C}$, while $67.44,65.00$ and $61.00 \%$ at 110 ${ }^{\circ} \mathrm{C}$. Present findings indicated that thermization process has no significant effect on the reduction of residues in sulfonamide contaminated milk. While sterilization process $\left(110{ }^{\circ} \mathrm{C}\right.$ for $\left.10 \mathrm{~min}\right)$ reduces up to $50 \%$ level of residues in sulfonamide spiked milk. Our results are supported by (Yassin et al. 2015) who stated that $\mathrm{N}^{4}$ aromatic group of sulfonamide reacts with reducing sugar to form a sugar sulfonamide complex which is more stable to heating at $100{ }^{\circ} \mathrm{C}$. Results are also supported by (Malik 2014), who reported that heat treatment up to $100{ }^{\circ} \mathrm{C}$ causes lower reduction of sulfonamide residues. It may be due to binding of sulfamethazine to protein and reducing sugars.

\section{Conclusions}

On the basis of present findings it could be concluded that thermization $\left(60{ }^{\circ} \mathrm{C}\right)$ poorly reduces antibiotics residues in milk. However penicillin $\mathrm{G}$, oxytetracyline and gentamycin residues in milk are considerably reduced with the pasteurization $\left(65^{\circ} \mathrm{C}\right)$ and sterilization $(110$ $\left.{ }^{\circ} \mathrm{C}\right)$. Thermostability of sulfonamide residues remains higher compared to penicillin $\mathrm{G}$, oxytetracyline and gentamycin residues. It was further concluded that complete elimination of antibiotics residues from milk by thermization, pasteurization and sterilization is not possible, however residues levels and their efficacy can be reduced. It is suggested to boil the milk at higher temperature in order to reduce the concentration as well as efficacy of antibiotics residues in milk, though otherwise may develop antimicrobial resistance in the consumers.

\section{References}

A.O.A.C. (2000) International. Official methods of analysis, 17th edition, 39-44.

Abbas, S., Ashraf, H., Nazir, A., Sarfraz, L. (2013) Physico-chemical analysis and 
composition of camel milk. International Researchers, 2, 84-98.

Berends, B.R., Bogaard, V.D., vanKnapen, E.J.M., Snijders, F.J.M.A. (2001) Human health hazards associated with the administration of antimicrobials to slaughter animals part I. An assessment of the risk of residues of Tetracycline in pork. Veterinary Quarterly, 23, 2-10.

Brady, M.S., Katz, S.E. (2016) Antibiotic/antimicrobial residues in milk. Journal of Food Protection, 51, 8-11.

Broggler, H., Juncher, H.O., Magnusson, I., Nogle. (2015) undersy!gelser over anvendeligheden af penicillinholdig maelk. Maanedsskr Dyrlaeger, 62, 217-223.

Conesa, C., Sanchez, L., Rota, C., Perez, M., Calvo, M. (2008) Isolation of lactoferrin from milk of different species: Calorimetric and antimicrobial studies. Compound Biochemistry and Physiology, 150, 131139.

DeJonghe, V., Coorevits, A., De Block, J., Van Coillie, E., Grijspeerdt, K., Herman, L., Heyndrickx, M. (2010) Toxinogenic and spoilage potential of aerobic spore-formers isolated from raw milk. International Journal of Food Microbiology, 136, 318325.

Ghidini, S., Zanardi, E., Varisco, G., Chizzolini, R. (2002) Prevalence of Molecules of $B$-Lactam Antibiotics in Bovine Milk in lombardia and Emili Aromagna (Italy). Journal of Annual Facultatis Medicine and Veterinary Parmacology, 22, 245-252.

Gomez, K.A., Gomez, A.A. (1984) Statistical procedures for agricultural research. An International Rice Research Institute Book. United State of America.

Hassani, M., Lázaro, R., Pérez, C., Condón, S., Pagán, R. (2008) Thermostability of oxytetracycline, tetracycline, and doxycycline at ultrahigh temperatures. Journal of Agriculture and Food Chemistry, 56, 2676-2680.

Hsieh, M.K., Shyu, C.L., Liao, J.W., Franje, C.A., Huang, Y.J., Chang, S.K., Shih, P.Y.,
Chou, C.C. (2011) Correlation analysis of heat stability of veterinary antibiotics by structural degradation, changes in antimicrobial activity and genotoxicity. Vet Med-Czech, 56, 274-285.

Jacquet, J., Auxepaules, M. (2012) Le proble 'me de la pollution du lait par les antibiotiques. E' tat actuel de la question. Bulletin Academia Ve 't de France, 51, 73 79.

Jones, G.M. (2008) On farm test for drug residues in milk, Virginia cooperative extension, Knowledge for the common wealth, Virginia Polytechnic and State University, U.S.A, 132-133.

Khopaibool, P. (2015) Effects of various heat treatments on Tetracycline HCL in milk. The 30th Kasetsart University Annual Conference in Bangkok, Thailand, 1, 403407.

Konec 'ny ', S. (2007) Effect of temperature and time on biological activity reduction of some kinds of antibiotics in milk. Veterinarstvu, 28, 409-410.

Kosikowsky, F.V., Henniugson, R.W., Silverman, G.J. (2013) The Incidence of Antibiotics, Sulfa Drugs and Quaternary Ammonium Compounds in the Fluid Milk Supply of New York State. Journal of Dairy Science, 35, 533-539.

KuKanich, B., Gehring, R., Webb, A.I., Craigmill, A.L., Riviere, J.E. (2005) Effect of formulation and route of administration on tissue residues and withdrawal times. Journal of American Veterinary Medical Association, 227, 1574-1577.

Loksuwan, J. (2002) Effect of heating on multiple residues of Tetracyclines in milk. Thammasat International Journal of Science and Technology, 7, 17-21.

Loksuwan, J. (2002) The effect of heating on multiple residues of tetracyclines in milk. Thammasat International Journal of Science and Technology, 7, 17-21.

Malik, S. (2014) Duncan SE. Extraction and Detection of Sulfamethazine in Spray-Dried milk. Journal of Dairy Science, 77, 418425. 
Moats, W.A. (2007) Stability of antibiotic residues on heat treatments. Journal of Food Protection, 51, 491-497.

Omar, R.H., Eltinay, A.H. (2008) Microbial quality of camel's raw milk in central southern region of United Arab Emirates. Emirates Journal of Food and Agriculture, 20, 76-83.

Overby, A. (2015) The Effect of Various Antibiotics iu Milk Following Intramammary Infusion. Nord Veterinary Medicine, 4, 993-1004.

Roca, M., Villegas, L., Kortabitarte, M.L., Althaus, R.L., Molina, M.P. (2011) Effect of heat treatments on stability of $\beta$-lactams in milk. Journal of dairy science, 94, 11551164.

Shahani, K.M. (2009) Factors Affectiug Terramycin Activity iu Milk, Broth, Buffer and Water. Journal Dairy Science, 41, 382 391.

Shahani, K.M. (2011) The Effect of Heat and Storage on the Stability of Aureomycin in Milk, Buffer and Water. Journal of Dairy Science, 40, 289-296.

Shetandi, A., Sternesjo, O. (2004) Factors contributing to the occurrence of antimicrobial drugs residues in Kenyan milk. Journal of Food Protection, 67, 399402.

Tropilo, J. (2015) Effect of heating on the inactivation of penicillin G. Medicine Veterinary, 41, 276-279.

Welch, H. (2005) Problems of Antibiotics in Food as the Food and Drug Administration Sees Them. American Journal of Public Health, 47, 701-705.

Welch, H., Jester, W.R., Burton, J.M. (2010) Antibiotics in Fluid Milk. Antibiotics and Chemotherapy, 5, 571-573.

Yassin, M.H., Soliman, M.M., Mostafa, S.A.E., Ali, H.A.M. (2015) Antimicrobial effects of camel milk against some bacterial pathogens. Journal of Food and Nutrition Research, 3, 162168.

Zorraquino, M.A., Roca, M., Fernández, N., Molina, M.P., Althaus, L. (2008) Heat inactivation of beta-lactam antibiotics in milk. Journal of Food Protection, 71, 1193-1198. 